\title{
Penggunaan Software ATLAS.ti sebagai Alat Bantu Proses Analisis Data Kualitatif
}

\author{
Ekasatya Aldila Afriansyah \\ STKIP Garut \\ e-mail: e_satya@yahoo.com
}

\begin{abstract}
ABSTRAK
Berdasarkan penelitian-penelitian yang telah dilakukan di Indonesia, khususnya di bidang pendidikan matematika, penelitian kualitatif masih kurang diminati. Hal ini menjadi salah satu dasar permasalahan yang ingin peneliti bahas yang bertujuan untuk menumbuhkan minat para peneliti dalam melakukan penelitian kualitatif dengan tujuan setelah para peneliti melihat penelitian ini, minat dari para peneliti muncul untuk melakukan penelitian kualitatif. Dalam penelitian ini, peneliti memperkenalkan salah satu software analisis data kualitatif dengan nama ATLAS.ti. Software ini berguna dalam membantu proses analisis data jenis penelitian kualitatif grounded theory, dalam pengolahan datanya setiap data diberi coding sehingga memudahkan peneliti nantinya untuk memanggil kembali data tersebut sebagai bahan diskusi dalam penelitiannya. Melalui penelitian ini, peneliti memiliki harapan agar muncul prosedur proses analisis data kualitatif berbantuan ATLAS.ti, melalui contoh penerapan pada salah satu kasus di bidang pendidikan matematika. Hasil dari penelitian ini berupa prosedur versi peneliti berdasarkan kasus yang peneliti gunakan.
\end{abstract}

Kata kunci: penelitian kualitatif, grounded theory, ATLAS.ti, coding

\begin{abstract}
According to some Indonesian research, especially in mathematics education, qualitative research is still less interested. It became one of basic problem that the researcher wants to discuss. Hoping after all researchers read this study, the interest of them appeared to do qualitative research. In this study, researcher introduced one of data analysis qualitative software, namely ATLAS.ti. This software was useful in helping with the process of data analysis qualitative research, especially grounded theory. Grounded theory, as ATLAS.ti, was given coding in any research data. It would be making easier for researchers to call back data later, or so on. Based on this helpful thing, researcher hoped through this research it would create a procedure data analysis qualitative research assisted by ATLAS.ti. This procedure appeared through an example of an application of one case in the field of mathematics education. The result of this research was a procedure based on the case of researcher used.
\end{abstract}

Keywords: qualitative research, grounded theory, ATLAS.ti, coding

\section{PENDAHULUAN}

Pada era penelitian sekarang ini, tidak banyak perubahan yang terjadi jika kita melihat dari sisi metode penelitian yang digunakan oleh para peneliti. Beberapa peneliti lebih memilih untuk menyusun penelitian kuantitatif, dan ada juga yang lebih memilih untuk melakukan penelitian kualitatif. Kedua metode ini, sudah bertahuntahun lamanya menjadi rival sebagai pilihan peneliti dalam menentukan metode penelitian yang digunakan (O’Donoghue, 2007). Seiring dengan berkembangnya dunia penelitian, ternyata kedua rival ini dapat berdiri beriringan dalam satu metode, yaitu metode campuran (kombinasi dari kuantitatif dan kualitatif dalam satu penelitian). Metode ini muncul dimungkinkan akibat dari ketidakpuasan peneliti dalam menggunakan salah satu metode yang telah ada. Perdebatan ini tidak akan menurunkan kualitas dari penelitian, justru akan memperkaya penelitian ke depannya.

Berkaitan dengan perdebatan tentang metode penelitian sebelumnya, para peneliti memiliki alasan tersendiri dalam memilih 
jenis dari metode penelitian yang akan mereka adaptasi dalam penelitiannya. Beberapa fakta ini, telah memberikan sumbangsih yang real terhadap munculnya alat bantu (software) analisis penelitian, baik itu kuantitatif maupun kualitatif. Alat bantu ini berkembang seiring dengan berjalannya waktu dan berkembangnya pengetahuan dari para peneliti. Sampai saat ini sudah bermunculan berbagai software kuantitatif maupun kualitatif, seperti SAS, R, SPSS, Mplus, HLM, Stata, Amos, Stat/Transfer, ATLAS.ti, MAXQDA, QSR Merge, Ethnograph, Nvivo dan N6. Berbagai macam software tersebut memiliki fungsi dan keunggulan tersendiri jika dibandingkan dengan software lainnya. Pada kesempatan kali ini, peneliti ingin membahas salah satu software yang dapat digunakan pada penelitian kualitatif yang masih jarang digunakan para peneliti Indonesia, khususnya di bidang pendidikan matematika.

Para peneliti di Indonesia, khususnya di bidang pendidikan matematika, masih memiliki kecenderungan untuk memilih kuantitatif sebagai metode penelitian mereka. Alasan mengapa mereka tidak memilih kualitatif, perlu observasi atau penelitian lebih lanjut. Sedangkan di era penelitian di dunia sekarang ini khususnya pendidikan matematika, penelitian kuantitatif dan kualitatif memiliki peminat yang berimbang atau bisa dikatakan lebih banyak ke penelitian kualitatif. Hal ini berbanding terbalik dengan situasi penelitian di Indonesia. Oleh karena itu, secara tidak langsung, peneliti ingin mengajak para peneliti di Indonesia untuk melakukan penelitian kualitatif dengan cara memperkenalkan salah satu software yang dapat digunakan, yaitu ATLAS.ti.

Dalam penelitian ini, peneliti memiliki pertanyaan penelitian "Bagaimana prosedur proses analisis data penelitian kualitatif berbantuan software ATLAS.ti?". Dalam pencarian prosedur tersebut, peneliti terapkan dalam studi literatur data penelitian
Afriansyah (2012). Melalui studi literatur ini, peneliti berharap dapat menjawab pertanyaan penelitian.

Peneliti bertujuan untuk menumbuhkan minat para peneliti Indonesia khususnya di bidang pendidikan matematika untuk melakukan penelitian kualitatif dengan memperkenalkan salah satu software yang dapat membantu proses analisis data kualitatif. Peneliti memiliki harapan setelah melihat penelitian ini, minat dari para peneliti muncul untuk melakukan penelitian kualitatif.

\section{KAJIAN TEORI}

\section{ATLAS.ti}

ATLAS.ti ini digunakan dalam penelitian kualitiatif. Software ini termasuk jenis program CAQDAS (Computer-Aided Qualitative Data Analysis Software) atau sama halnya dengan QDA software (Qualitative Data Analysis Software). Dalam penamaan software ini, masyarakat umum lebih mengenal nama atlas ini sebagai kumpulan peta (model dari dunia, sebuah globe) yang dapat membantu kita agar sampai ke tempat tujuan. Berbeda cerita dengan bangsa Yunani, mereka lebih mengenal nama atlas ini sebagai nama pahlawan di negaranya. Sementara itu, kasus berbeda untuk penamaan software ATLAS.ti sendiri. Dilihat dari sejarahnya, pencetus software ATLAS.ti ini bernama Thomas Muhr, berasal dari Jerman. Dikarenakan hal tersebut, dalam Bahasa Jerman ATLAS.ti memiliki singkatan Archiv fur Technik, Lebenswelt, Alltags Sprache (Archieve of Technology, Lifeworld and Everyday Language). Nama ATLAS menopang ide sebagai peta dunia dan ini digambarkan dalam pengelolaan dokumen yang bermakna. Sementara untuk singkatan ti dalam penamaan software tersebut, memberikan makna interpretasi teks (Friese, 2014).

Dari tahun ke tahun, ATLAS.ti berkembang seiring dengan perkembangan Jurnal "Mosharafa", Volume 5, Nomor 2, Mei 2016 ISSN 20864280 
penelitian. Sekarang ini, untuk update terbaru sudah mencapai ATLAS.ti 7. Software ini pun ternyata cukup banyak penggunanya di dunia sehingga memiliki konferensi tersendiri yang diadakan setiap tahunnya, dimulai sejak tahun 2013 yang diselenggarakan di tempat lahirnya software ini yaitu Berlin, Jerman. Laporan tentang konferensinya dapat dilihat dalam pelaporan dari Evers \& Silver (2014), mereka mendeskripsikan bagaimana konferensi berlangsung, dan siapa saja yang berbicara dalam konferensi tersebut.

ATLAS.ti dapat membantu kita mengorganisasi, memberikan kode, dan menganalisis data penelitian kita secara efisien dan terstruktur. Software ini mampu membaca berbagai jenis data, seperti data audio, data video, data gambar, maupun data tertulis (artikel, buku, data survey, ataupun transkip wawancara). Hal ini memungkinkan kita dalam melakukan trianggulasi dengan berbagai jenis pengumpulan data. Sejalan dengan apa yang telah dikatakan oleh Drijvers (2012), ATLAS.ti memiliki empat keunggulan jika dibandingkan dengan software lainnya, yaitu: (1) ATLAS.ti dapat membaca berbagai macam jenis data, (2) software ini pun popular dikalangan peneliti kualitatif, bukti dari kepopuleran software ini salah satunya adalah konferensi khusus yang dimiliki oleh para pengguna ATLAS.ti, (3) ATLAS.ti memiliki panduan yang baik, terdapat bantuan secara online, dan dokumentasi lengkap, dan (4) harganya terjangkau.

Walaupun memiliki beberapa keunggulan yang telah disebutkan sebelumnya, Friese (2014) dalam bukunya mengatakan bahwa ATLAS.ti ini sama halnya seperti software kualitatif lainnya, tidak benar-benar menganalisa data, hanya alat bantu sederhana yang dapat membantu proses analisis data kualitatif. Hal ini dibenarkan oleh beberapa peneliti yang menggunakan ATLAS.ti. Berikut beberapa penelitian yang telah menggunakan software ATLAS.ti dalam penelitiannya, sebagai berikut:

1. Van Nes \& Doorman (2010) menganalisis data penelitiannya secara kualitatif dibantu dengan software ATLAS.ti dalam pemberian kode.

2. Doorman dkk (2012) menggunakan ATLAS.ti sebagai alat bantu proses analisis data kualitatif, dimulai dari pengorganisasian data, pemberian kode, sampai pendeskripsian data.

3. Jupri (2015) dalam penelitiannya melakukan analisa data melalui tiga langkah dengan bantuan ATLAS.ti, yaitu: (1) pengorganisasian data sesuai dengan klasifikasinya, (2) pendeskripsian data sesuai dengan kategorinya, dan (3) hasil di cek ulang melalui koding yang telah diberikan di awal analisis.

Dalam artikel ini, peneliti akan menyajikan penerapan ATLAS.ti melalui kajian literatur Afriansyah (2012). Hal ini dimaksudkan agar para peneliti lainnya khususnya di bidang pendidikan matematika memiliki gambaran dalam mengaplikasikan software ATLAS.ti ini ke dalam penelitiannya. Dikarenakan pada kenyataannya kasus yang ada pada panduan ATLAS.ti ini adalah kasus umum, yaitu ranah kesehatan.

Sementara itu, kembali pada bidang pendidikan matematika, salah seorang peneliti dari Belanda yang bernama Drijvers berpendapat bahwa software ATLAS.ti ini memiliki alur yang sistematik, sesuai dengan standar metode penelitian kualitatif design research yang telah menjadi tradisi lama FISME (Freudenthal Institute for Science and Mathematics Education). Selain itu, software ini pun memiliki dasar grounded theory, dan itu bersesuaian dengan penelitian-penelitian di dalam FISME. 
Dalam penerapannya, perlu kita ketahui bagaimana prosedur penggunaan software ATLAS.ti. Van Nes (2009) mengungkapkan

menggunakan bagaimana ATLAS.ti penelitiannya. ATLAS.ti membantu mengorganisir data mentah penelitiannya, dan juga membantu memberikan coding pada masing-masing data yang telah dikategorisasi. Berikut penjelasan Van Nes yang telah dianalisis lebih mendalam oleh peneliti, yaitu:

1. Kita memilah masing-masing pertanyaan di dalam wawancara ke dalam sebuah kutipan. Secara umum, data yang perlu ditandai sebagai kutipan tidak diharuskan berupa hasil wawancara, dapat berupa data lain seperti literatur dari penelitian relevan, hasil kerja siswa, catatan peneliti, foto dan/atau video pembelajaran.

2. Kita mengkategorikan masing-masing temuan dari kutipan yang telah diinputkan ke dalam software, dan menandai ke dalam daftar kode yang kita inginkan. Kutipan-kutipan tersebut diklasifikasikan ke dalam beberapa kode yang telah ditentukan menurut penelitian relevan ataupun temuan dari peneliti sendiri.

3. Kita menganalisis data wawancara dengan menghubungkan kode yang relevan pada masing-masing kutipan yang telah ditandai. Berbagai data temuan yang ingin dipaparkan oleh peneliti diperkuat oleh hubungan dari kode dan kutipan yang telah dibuat sehingga nantinya dapat kita lihat gambaran temuan tersebut (semacam network/jaringan dari temuan itu).

Prosedur penerapan ATLAS.ti lainnya dipaparkan oleh Drijvers (2012), digambarkan dalam bentuk bagan (Gambar 1) sebagai berikut:

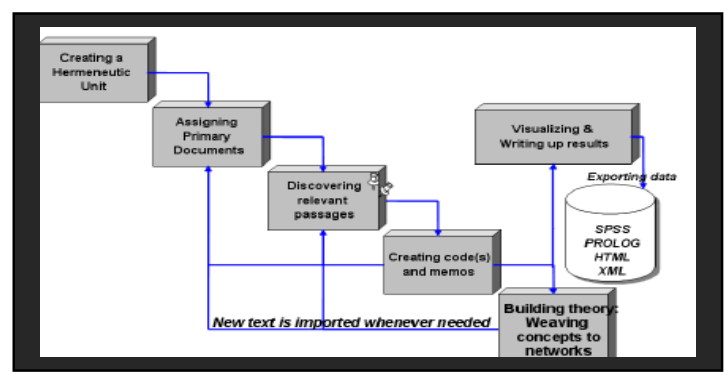

Gambar 1. Prosedur penerapan ATLAS.ti menurut Drijvers (2012)

\section{Desain penelitian kualitatif (grounded theory)}

Berbicara tentang penelitian kualitatif, para peneliti Indonesia sendiri khususnya di bidang pendidikan matematika, masih cukup jarang yang menggunakannya. Hal ini dikarenakan peminat dari penelitian kualitatif ini masih kalah dibandingkan metode penelitian lain. Peneliti memberikan pernyataan ini sesuai dengan apa yang dilihat oleh peneliti di lapangan dan hasil observasi peneliti di institusi tertentu. Peneliti melakukan observasi kecil terhadap para mahasiswa di tingkat tertentu dalam mengajukan tugas akhirnya. Hasil observasi tersebut menghasilkan mahasiswa yang memilih penelitian kualitatif ini hanya $10 \%$ saja. Oleh karena itu, perlunya kita mengkaji lebih lanjut penelitian kualitatif ini sebagai awal mula dalam mengembangkan penelitian kualitatif di Indonesia.

Menurut Creswell (2012), tipe desain penelitian kualitatif ini dapat diklasifikasikan berdasarkan tiga hal, yaitu:

1. Fenomena utama berdasarkan ketertarikan terhadap suatu hal (cth. budaya kelompok tertentu, atau individu tertentu),

2. Tujuan penelitian (cth. untuk menggambarkan dan menginterpretasikan, atau mengembangkan sebuah teori), dan

3. Prosedur inti penelitian (cth. bagaimana data diperoleh, dianalisis, dan diinterpretasi; dan bagaimana hasil penelitian dilaporkan)

Dari ketiga hal tersebut, Clark \& Creswell (2014) mengungkap beberapa jenis 
desain penelitian kualitatif. Gambaran jenis- dipaparkan dalam tabel 1. sebagai berikut: jenis desain penelitian kualitatif ini

Tabel 1. Jenis desain penelitian kualitatif menurut Clark \& Creswell (2014)

\begin{tabular}{|c|c|c|c|}
\hline Nama Desain & Fenomena utama & Tujuan & Prosedur Inti \\
\hline $\begin{array}{l}\text { Basic } \\
\text { qualitative } \\
\text { research } \\
\text { approach }\end{array}$ & Topik tertentu & $\begin{array}{l}\text { Untuk } \\
\text { mengeksplorasi } \\
\text { berbagai pendapat }\end{array}$ & $\begin{array}{l}\text { Mengumpulkan data kualitatif, menganalisis data } \\
\text { untuk membangun sebuah tema, dan } \\
\text { mendiskusikan kesimpulan umum tentang tema } \\
\text { tersebut }\end{array}$ \\
\hline $\begin{array}{l}\text { Autoethnogra } \\
\text { phy }\end{array}$ & $\begin{array}{l}\text { Pengalaman } \\
\text { peneliti pribadi }\end{array}$ & $\begin{array}{l}\text { Untuk memahami } \\
\text { suatu permasalahan } \\
\text { budaya yang besar }\end{array}$ & $\begin{array}{l}\text { Merekam, merefleksi, dan menganalisis data } \\
\text { tentang pengalaman pribadi peneliti dalam } \\
\text { konteks budaya yang besar }\end{array}$ \\
\hline Case study & $\begin{array}{l}\text { Suatu aturan } \\
\text { manusia (sebuah } \\
\text { kasus) yang diikat } \\
\text { oleh ruang dan } \\
\text { waktu }\end{array}$ & $\begin{array}{l}\text { Untuk } \\
\text { menggambarkan dan } \\
\text { menginterpretasikan } \\
\text { apa yang terjadi }\end{array}$ & $\begin{array}{l}\text { Mengumpulkan dan menganalisis berbagai } \\
\text { bentuk data sebagai gambaran, tema, dan } \\
\text { pembelajaran yang telah dipelajari }\end{array}$ \\
\hline $\begin{array}{l}\text { Discourse } \\
\text { analysis }\end{array}$ & $\begin{array}{l}\text { Bagaimana } \\
\text { individu } \\
\text { mengkomunikasik } \\
\text { an sebuah topik }\end{array}$ & $\begin{array}{l}\text { Untuk memeriksa } \\
\text { penggunaan bahasa }\end{array}$ & $\begin{array}{l}\text { Mengumpulkan data secara apa adanya yang } \\
\text { muncul secara tertulis ataupun tertulis dan } \\
\text { menganalisis bagaimana penggunaan bahasa } \\
\text { dalam data (daripada memfokuskan pada isi dari } \\
\text { data tersebut) }\end{array}$ \\
\hline Ethnography & $\begin{array}{l}\text { Bahasa, tingkah } \\
\text { laku, dan } \\
\text { kepercayaan (cth } \\
\text { budaya) pada } \\
\text { suatu komunitas }\end{array}$ & $\begin{array}{l}\text { Untuk } \\
\text { menggambarkan } \\
\text { kebiasaan dari suatu } \\
\text { budaya }\end{array}$ & $\begin{array}{l}\text { Mengumpulkan data utama melalui observasi } \\
\text { dan menganalisis data untuk mendeskripsikan } \\
\text { kebiasaan dari suatu budaya melalui bahasa } \\
\text { sehari-hari, tingkah laku, dan sikap dari suatu } \\
\text { komunitas }\end{array}$ \\
\hline $\begin{array}{l}\text { Grounded } \\
\text { theory }\end{array}$ & $\begin{array}{l}\text { Sebuah proses, } \\
\text { sikap, atau } \\
\text { interaksi }\end{array}$ & $\begin{array}{l}\text { Untuk menghasilkan } \\
\text { sebuah teori }\end{array}$ & $\begin{array}{l}\text { Mengumpulkan data, mengidentifikasi dan } \\
\text { menghubungkan kategori di dalam data, } \\
\text { membuat suatu gambar yang melukiskan suatu } \\
\text { teori, dan menyatakan dugaan dari teori tersebut }\end{array}$ \\
\hline $\begin{array}{l}\text { Historical } \\
\text { analysis }\end{array}$ & Peristiwa yang lalu & $\begin{array}{l}\text { Untuk } \\
\text { merekonstruksi suatu } \\
\text { sejarah }\end{array}$ & $\begin{array}{l}\text { Mengumpulkan artifak yang merepresentasikan } \\
\text { baerbagai sumber data tentang peristiwa tertentu, } \\
\text { mengevaluasi kebenaran artifak tersebut, dan } \\
\text { merekonstruksi peristiwa tertentu }\end{array}$ \\
\hline $\begin{array}{l}\text { Narrative } \\
\text { research }\end{array}$ & $\begin{array}{l}\text { Pengalaman } \\
\text { seseorang atau } \\
\text { lebih }\end{array}$ & $\begin{array}{l}\text { Untuk } \\
\text { mendeskripsikan arti } \\
\text { dari pengalaman } \\
\text { tersebut melalui } \\
\text { cerita }\end{array}$ & $\begin{array}{l}\text { Mengumpulkan data seperti catatan lapangan } \\
\text { dari catatan pribadi sumber, menganalisis data } \\
\text { untuk membangun sebuah cerita, dan } \\
\text { menceritakan kembali cerita tersebut dan } \\
\text { mengidentifikasi konteks dan tema dari cerita } \\
\text { tersebut }\end{array}$ \\
\hline $\begin{array}{l}\text { Phenomenolo } \\
\text { gy }\end{array}$ & $\begin{array}{l}\text { Sebuah } \\
\text { pengalaman }\end{array}$ & $\begin{array}{l}\text { Untuk } \\
\text { mendeskripsikan } \\
\text { suatu makna }\end{array}$ & $\begin{array}{l}\text { Mengumpulkan data dari seseorang yang } \\
\text { memiliki pengalaman tersebut, menganalisis data } \\
\text { yang bermakna berupa suatu pernyataan yang } \\
\text { berpengaruh penting, dan mendeskripsikan tema } \\
\text { dan/tentang pentingnya suatu pengalaman }\end{array}$ \\
\hline Photovoice & $\begin{array}{l}\text { Keadaan individu } \\
\text { seseorang }\end{array}$ & $\begin{array}{l}\text { Untuk } \\
\text { menginformasikan } \\
\text { keadaan seseorang } \\
\text { melalui bentuk visual } \\
\text { ataupun tulisan }\end{array}$ & $\begin{array}{l}\text { Menyediakan kamera pada individu tersebut dan } \\
\text { meminta mereka untuk mengambil gambar dari } \\
\text { suatu keadaan yang menjadi permasalahan, } \\
\text { mewawancarai mereka tentang foto tersebut, dan } \\
\text { mempresentasikan foto tersebut dalam bentuk } \\
\text { gambar dan tulisan }\end{array}$ \\
\hline Portraiture & $\begin{array}{l}\text { Permasalahan } \\
\text { sehari-hari }\end{array}$ & $\begin{array}{l}\text { Untuk mendapatkan } \\
\text { suatu gambaran } \\
\text { situasi yang } \\
\text { baik/benar tentang } \\
\text { permasalahan } \\
\text { tertentu dari }\end{array}$ & $\begin{array}{l}\text { Mengumpulkan data yang utama melalui } \\
\text { wawancara, memposisikan peneliti dalam } \\
\text { penelitiannya, dan membuat suatu gambaran } \\
\text { tentang apa yang dipelajari dari ahlinya. }\end{array}$ \\
\hline
\end{tabular}

Jurnal “Mosharafa”, Volume 5. Nomor 2, Mei 2016 
Dari sekian banyaknya jenis desain penelitian kualitatif di atas, peneliti menggunakan desain penelitian grounded theory. Desain penelitian grounded theory ini merupakan sekumpulan prosedur kualitatif yang sistematik, digunakan oleh para peneliti untuk menghasilkan sebuah penjelasan (disebut grounded theory) yang menjelaskan suatu proses, tindakan, atau interaksi diantara sejumlah orang yang diteliti (Clark \& Creswell, 2014). Teori ini menjelaskan terdapat kemungkinan hubungan antar konsep, dan dikatakan grounded theory karena penjelasan dari pengumpulan dan analisis data kualitatifnya dibangun dari (atau grounded dalam) sebuah pengalaman dan pandangan dari sampel yang diteliti.

Desain penelitian grounded theory ini digunakan oleh para peneliti dengan tujuan untuk membangun sebuah teori baru, disertai penjelasan yang mendukung teori tersebut. Teori ini lahir "grounded" melalui data yang telah dikumpulkan dan dianalisis yang ditemukan selama penelitian berupa proses, tindakan, ataupun interaksi yang terjadi didalamnya. Banyaknya sampel yang dibutuhkan dalam desain penelitian grounded theory ini adalah 20-30 orang.

\section{PEMBAHASAN}

Peneliti mengkaji ulang data penelitian yang sudah dilakukan peneliti sebelumnya dengan judul "Design Research: Konsep Nilai Tempat pada Operasi Penjumlahan Bilangan Desimal di Kelas V Sekolah Dasar" tahun 2012, dengan alasan peneliti ingin mengetahui proses analisis sebelum dan sesudah menggunakan software ATLAS.ti. Selain itu, pengambilan literatur Afriansyah (2012) ini dapat memberikan gambaran yang jelas tentang bagaimana software ATLAS.ti diterapkan dalam desain penelitian kualitatif khususnya di bidang pendidikan matematika.

Adapun prosedur analisis data dalam penelitian ini terbagi menjadi dua bagian, yaitu: pengumpulan dan analisis data penelitian sebelumnya (Afriansyah, 2012) dan penerapan data penelitian dengan berbantuan software ATLAS.ti (prosedur pengolahan data dengan ATLAS.ti).

Untuk pengumpulan dan analisis data penelitian sebelumnya (Afriansyah, 2012), penelitian ini menggunakan design research, terdapat tiga fase dalam melakukan design research tersebut (Gravemeijer \& Cobb, 2006). Pertama, Preliminary design, pada fase ini peneliti mengkaji literatur dan merancang suatu HLT (Hypothetical Learning Trajectory) awal, melakukan observasi kelas, meneliti kemampuan awal siswa, dan berdiskusi dengan guru. Kedua, Teaching experiment (1st and 2nd cycle), di siklus pertama peneliti mengujicobakan HLT, lalu memperbaikinya. HLT yang sudah diperbaiki, diujicobakan kembali pada siklus kedua. Ketiga, Retrospective analysis, melakukan analisis data yang dilakukan di setiap siklus setelah fase teaching experiment. Pada fase ini peneliti memperbaiki HLT yang telah diujicobakan sehingga HLT tersebut nantinya dapat diangkat menjadi sebuah teori baru.

Untuk analisis data dalam penelitian ini dilakukan terhadap berbagai situasi, dimulai dari tes awal, percobaan mengajar di setiap aktivitas yang diberikan, dan tes akhir. Beberapa situasi tersebut dianalisis dalam dua siklus. Pembahasan analisis di setiap siklus diposisikan pada fase Retrospective analysis. Pada siklus pertama, tidak banyak temuan yang berarti diluar dugaan peneliti sehingga revisi hanya dilakukan pada soal (perubahan dari segi bahasa dan banyak soal saja). Perubahan penyampaian guru pun dilakukan dengan harapan tujuan dari setiap aktivitas ini dapat tersampaikan lebih baik lagi. Pada siklus kedua, terdapat temuan kekeliruan siswa terhadap pemahaman bilangan desimal (kepadatan desimal, penjumlahan desimal, dan konsep nilai tempat desimal). Kekeliruan- 
kekeliruan tersebur dipaparkan pada setiap bagiannya secara deskriptif dilengkapi dengan lampiran foto hasil pekerjaan siswa ataupun gambaran situasi. Dari apa yang diperoleh melalui dua siklus yang berbeda, HLT direvisi kembali sehingga menghasilkan LT (Learning Trajectory), atau dapat dikatakan LIT (Local Instruction Theory) dalam penjumlahan bilangan desimal. Berikut merupakan teori yang dihasilkan pada penelitian Afriansyah (2012), digambarkan dalam sebuah proses lintasan pembelajaran pada topic penjumlahan bilangan desimal (Gambar 2).

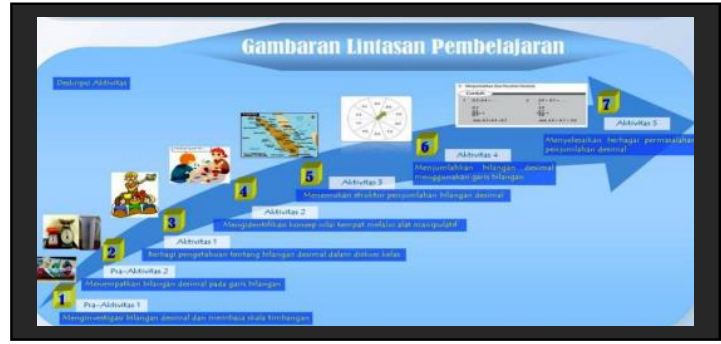

Gambar 2. Lintasan pembelajaran pada penjumlahan bilangan desimal

Untuk penerapan data penelitian dengan bantuan software ATLAS.ti (prosedur pengolahan data dengan ATLAS.ti), peneliti mencoba menggambarkan sendiri bagaimana penerapan ATLAS.ti ini dalam beberapa tahapan sederhana. Prosedur analisis data dengan bantuan ATLAS.ti ini meliputi:

1. Membuat HU (Heurmeunistic Unit), sebagai langkah awal dalam penggunaan software ATLAS.ti. Seperti halnya membuat dokumen baru di dalam Microsoft Office Word, lalu beri nama HU tersebut (Gambar 3). Dalam penelitian ini, peneliti memberikan nama "Tesis Ekasatya A Afriansyah".

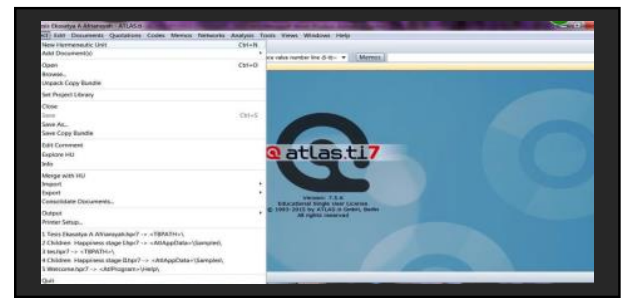

Gambar 3. Tampilan langkah membuat HU

2. Input data: Membuat beberapa PD (Primary Document), masukkan data yang ingin di analisis ke dalam software ATLAS.ti, data dapat berupa text, pdf, gambar, foto, audio, ataupun video. Secara tidak langsung beberapa PD terekam oleh ATLAS.ti sebanyak dengan data yang telah dimasukkan. Untuk melihat beberapa PD yang telah dimasukkan, dapat kita lihat dalam satu tampilan Primary Document Manager (Gambar 4).

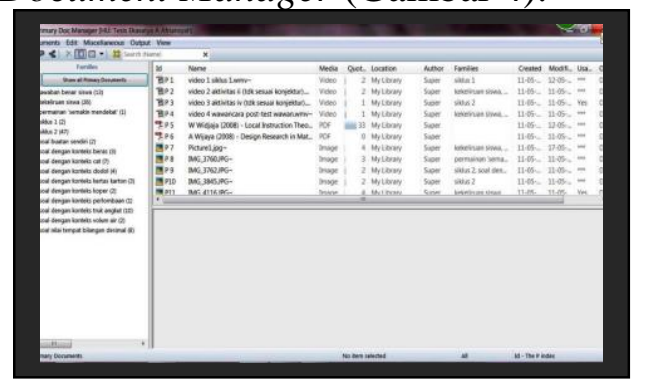

Gambar 4. Tampilan Primary Document Manager

3. Memilih data: Membuat beberapa quotation dari setiap data yang sekiranya penting bagi peneliti. Dalam suatu penelitian, tidak jarang peneliti menemukan pernyataan ataupun suatu hal yang menarik perhatian sebagai bahan penunjang data penelitian. Dengan cara memberikan quotation di setiap data, ATLAS.ti memberikan kemudahan kepada para peneliti untuk menyimpan dokumen penunjang dan nantinya dapat dengan mudah peneliti panggil kembali. Quotation yang telah dibuat, dapat dilihat dalam Quotation Manager. Berikut contoh gambaran quotation yang terdapat pada 
penelitian ini dalam beberapa macam data (Gambar 5, 6, dan 7).

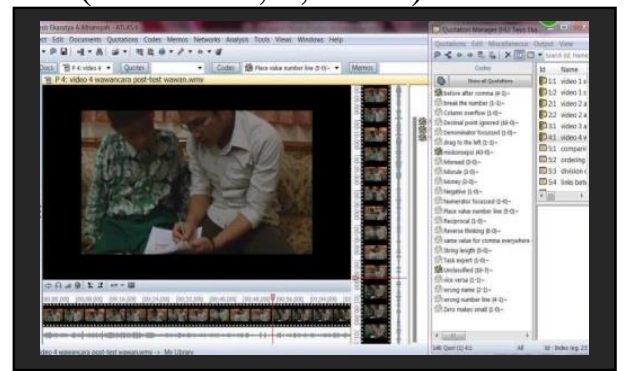

Gambar 5. Tampilan quotation pada data video

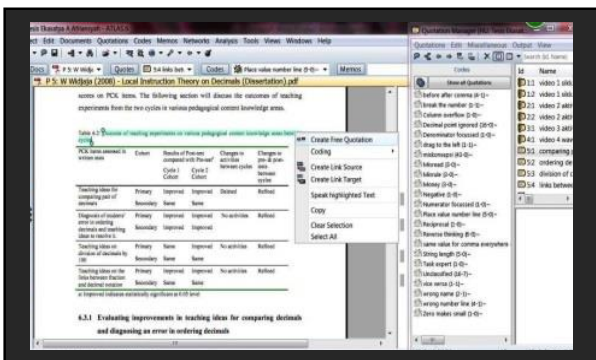

Gambar 6. Tampilan quotation pada data $p d f$

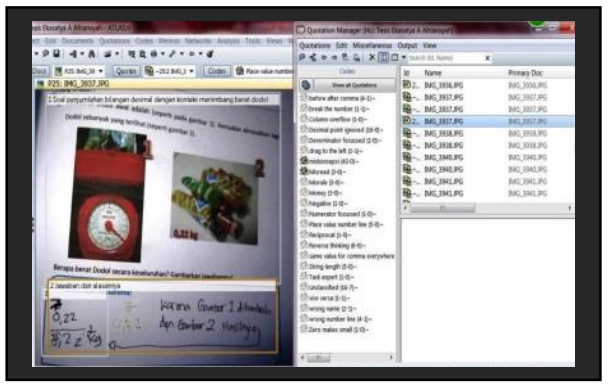

Gambar 7. Tampilan quotation pada data gambar/jpg/jpeg

4. Memberikan coding: Menentukan kode yang akan digunakan (disesuaikan menurut sumber ataupun temuan pribadi) dan menandai data dengan kode yang sesuai. Penentuan kode dalam penelitian ini difokuskan terhadap temuan dari penelitian rujukan penelitian Steinle (dalam Widjaja, 2008) dan temuan peneliti sendiri (Afriansyah, 2012). Berikut gambaran kode yang dibuat pada Code Manager (Gambar 8).

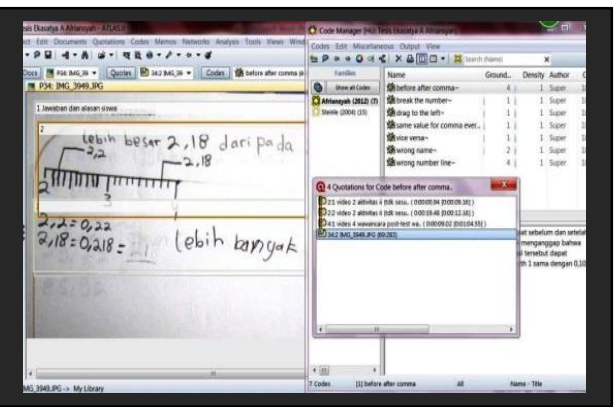

Gambar 8. Tampilan Code Manager

5. Melakukan analisis: Membuat suatu gambaran jaringan (network). Gambaran jaringan ini dapat membantu peneliti dalam menelusuri hubungan dari temuan yang akan dianalisis dengan temuan-temuan lainnya ataupun dengan kutipan dan/atau kode yang telah ditandai. Berikut contoh gambar network pada penelitian ini (Gambar 9).

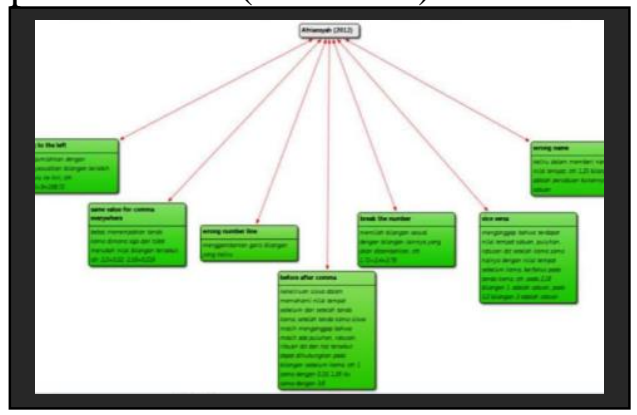

Gambar 9. Tampilan contoh network

6. Mencari data: Menggunakan Query tool, peneliti dapat menganalisis hubungan antara masing-masing data melalui kode yang telah dibuat sebelumnya pada setiap data. Pada penelitian ini, peneliti memberikan contoh dalam mencari data yang berhubungan antara kode Afriansyah (2012) dengan salah satu temuannya yaitu wrong number line (Gambar 10). Dari gamba tersebut, terdapat empat data yang menunjukkan adanya hubungan antara kedua hal tersebut. 


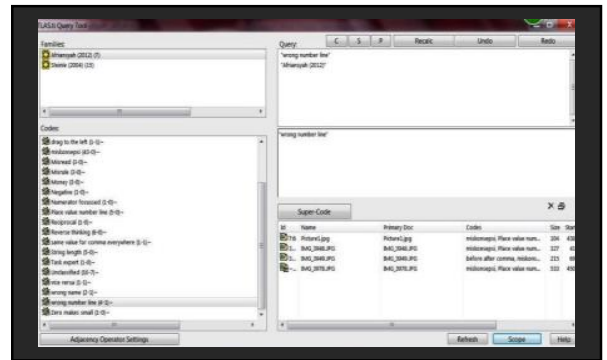

Gambar 10. Tampilan Query Tool

7. Membuat memo, digunakan untuk mendokumentasikan/memberikan komentar terhadap analisismu. Berikut contoh gambaran memo pada penelitian ini (Gambar 11).

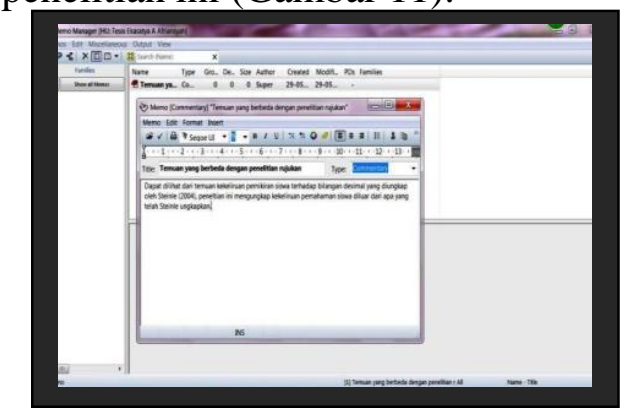

Gambar 11. Tampilan Memo Manager

8. Menghasilkan suatu output, luaran yang dapat diperoleh dari analisis data berbantuan ATLAS.ti ini berupa XML, table/bagan, HTML, PROLOG Editor, ataupun SPSS (Gambar 12).

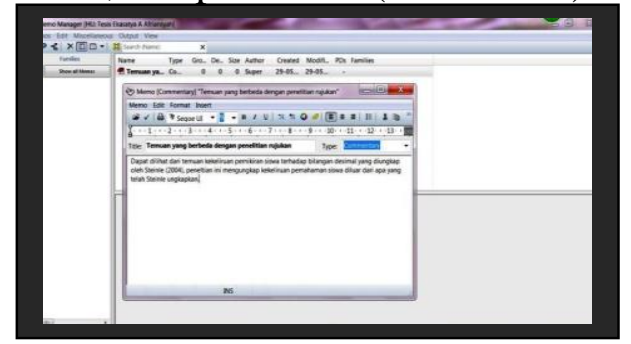

Gambar 12. Tampilan pembuatan output

Beberapa hal yang dapat menjadi catatan di dalam penelitian ini yaitu kebermanfaatan software ATLAS.ti dalam membantu peneliti menganalisis data. Walaupun benar dengan apa yang dikatakan Friese (2014) bahwa ATLAS.ti ini tidak mengolah data dengan sendirinya seperti halnya software-software lain dalam penelitian kuantitatif, ATLAS.ti ini pada kenyataannya telah cukup banyak membantu peneliti. ATLAS.ti memiliki caranya sendiri sebagai fungsinya dalam membantu proses analisis data, seperti halnya mengorganisir data dengan baik, menyimpan rapi data penelitian, memudahkan peneliti dalam memanggil data yang diperlukan melalui kode yang telah ditandai sebelumnya, mencari tahu hubungan antar data penelitian, dan lainlain. Banyaknya bantuan yang diberikan ATLAS.ti ini memperkuat keyakinan kita sebagai peneliti untuk menggunakannya ketika kita melakukan penelitian kualitatif.

\section{PENUTUP \\ Simpulan}

Dalam penelitian ini, melalui data Afriansyah (2012) yang diolah kembali dengan menggunakan software ATLAS.ti, peneliti ingin memaparkan jawaban pertanyaan penelitian yang telah diajukan sebelumnya. Hasilnya berupa gambaran prosedur dalam proses analisis data penelitian kualitatif secara visual. Berikut merupakan prosedur analisis penelitian kualitatif berbantuan ATLAS.ti: (1) Membuat HU (Heurmeunistic Unit), (2) Input data dengan membuat beberapa PD (Primary Document), (3) Memilih data dan membuat beberapa quotation, (4) Memberikan coding, (5) Membuat suatu gambaran network, (6) Mencari data dengan menggunakan Query tool, (7) Membuat memo dengan memberikan komentar pada setiap data analisismu, dan (8) Menghasilkan suatu output.

\section{Saran}

Melalui penelitian ini, peneliti menyarankan kepada para peneliti di Indonesia, khususnya peneliti di bidang pendidikan matematika, untuk dapat melakukan penelitian kualitatif dan menerapkan software ATLAS.ti agar memudahkan peneliti dalam proses analisis data. 
UCAPAN TERIMA KASIH

Penulis berterima kasih kepada Drs. Turmudi, M.Ed., M.Sc., Ph.D. atas bimbingan dan dukungannya dalam penyusunan artikel ilmiah ini.

\section{DAFTAR PUSTAKA}

Afriansyah, E. A. (2012). Design Research: Konsep Nilai Tempat pada Penjumlahan Bilangan Desimal. Tesis yang tidak dipublikasikan berasal dari Beasiswa DIKTI dengan program IMPoME (International Master Program on Mathematics Education). Universitas Sriwijaya Palembang - $\quad$ Universitas UTRECHT Belanda.

Creswell, J. W. (2012). Educational research. Planning, conducting, and evaluating quantitative and qualitative research (4th ed.). Boston, MA: Pearson.

Clark, V. L. P. \& Creswell, J. W. (2014). Understanding Research (2nd Edition). Pearson Education, Inc.

Doorman, M., Drijvers, P., Gravemeijer K., Boon P., \& Reed H. (2012). Tool use and the development of the function concept: From repeated calculations to functional thinking. International Journal of Science and Mathematics Education 10: 1243-1267.

Drijvers, P. (2012). Analysing qualitative data with ATLAS.ti. Modul Presentation in Freudenthal Institute: (pp. 1-37). The Netherlands: Utrecht University.

Evers, J. \& Silver, C. (2014). Conference Report: The First ATLAS.ti User Conference [23 paragraphs]. Forum
Qualitative Sozialforschung / Forum: Qualitative Social Research, 15(1), Art. 19.

Friese, S. (2014). Qualitative Data Analysis with ATLAS.ti (2nd Ed). SAGE Publications.

Gravemeijer, K., \& Cobb, P. (2006). Design research from the learning design perspective. Educational design research (pp. 17-51). London: Routladge.

Jupri, A. (2015). The use of applets to improve Indonesian student performance in algebra. Unpublished Dissertation of Freudenthal Institute for Science and Mathematics Education, Faculty of Science. The Netherlands: Utrecht University.

O'Donoghue, T. (2007). Planning your qualitative research project, An introduction to interpretivist research in education. London \& New York: Routledge Taylor \& Francis Group.

Steinle, V. (2004). Changes with age in students' misconceptions of desimal numbers. Unpublished $\mathrm{PhD}$ thesis, University of Melbourne, Melbourne.

Van Nes, F. (2009). Young Children's Spatial Structuring Ability and Emerging Number Sense. Unpublished Dissertation of Freudenthal Institute for Science and Mathematics Education, Faculty of Science. The Netherlands: Utrecht University.

Van Nes, F. \& Doorman, M. (2010). The Interaction Between Multimedia Data Analysis and Theory Development in Design Research. 
Mathematics Education Research

Journal Vol. 22, No. 1: 6-30.

Widjaja, W. (2008). Local Instruction Theory on Desimals: The Case of Indonesian Pre-Service Teachers. Unpublished $\mathrm{PhD}$ thesis. Australia: University of Melbourne.

\section{RIWAYAT HIDUP PENELITI}

Ekasatya Aldila Afriansyah, M.Sc..

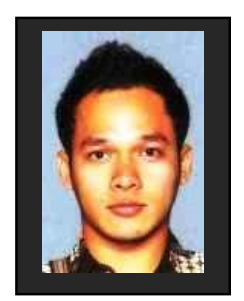

Lahir di Bandung, 4 April

1986. Dosen Tetap

Yayasan STKIP Garut.

Studi S1 Matematika

Konsentrasi Statistika UPI,

Bandung, lulus tahun 2009;

S2 Pendidikan Matematika

UNSRI-UTRECHT, Palembang-Utrecht, lulus tahun 2012; dan S3 Pendidikan Matematika UPI, Bandung, sampai sekarang. 